\title{
Mapping potential fishing zones for skipjack tuna in the southern Makassar Strait, Indonesia, using Pelagic Habitat Index (PHI)
}

\author{
ANDI RANI SAHNI PUTRI ${ }^{1}$, MUKTI ZAINUDDIN ${ }^{1, \bullet}$, MUSBIR $^{1}$, MUZZNEENA AHMAD MUSTAPHA ${ }^{2}$, \\ RACHMAT HIDAYAT \\ ${ }^{1}$ Department of Fisheries, Faculty of Marine Science and Fisheries, Universitas Hasanuddin. Jl. Perintis Kemerdekaan Km. 10, Makassar 90245, South \\ Sulawesi, Indonesia. Tel./fax.: +62-411-586025, `email: muktizunhas@gmail.com \\ ${ }^{2}$ School of Environmental and Natural Resource Sciences, Faculty of Science and Technology, Universiti Kebangsaan Malaysia. 43600 Bangi, Selangor, \\ Malaysia
}

Manuscript received: 24 June 2021. Revision accepted: 29 June 2021.

\begin{abstract}
Putri ARS, Zainuddin M, Musbir, Mustapha MA, Hidayat R. 2021. Mapping potential fishing zones for skipjack tuna in the southern Makassar Strait, Indonesia, using Pelagic Habitat Index (PHI). Biodiversitas 22: 3037-3045. Southern Makassar Strait is one of the potential fishing grounds for skipjack tuna in the Indonesian waters. Oceanographic factors become the primary factors that limit the distribution and abundance of fish. The study aimed to identify the relationship between fish distribution with sea surface temperature (SST) and primary productivity (PP) and map out the potential fishing grounds of skipjack tuna in the southern Makassar Strait. It used pelagic habitat index (PHI) analysis, which is strengthened by the results of correlation analysis in the form of generalized additive models (GAM) and Empirical cumulative distribution function $(\mathrm{ECDF})$ analysis. The results showed that the distribution of skipjack tuna was significantly associated with the preferred range of SST $29-30.5^{\circ} \mathrm{C}$ and PP $350-400 \mathrm{mg} \mathrm{C} / \mathrm{m}^{2} /$ day. The potential fishing zone is well established near the coast to offshore of Barru and Polman waters $\left(3^{\circ}-6^{\circ} \mathrm{S}\right.$ and $\left.117^{\circ}-119^{\circ} \mathrm{E}\right)$, with the peak season in May and October. The spatial pattern of potential fishing grounds for skipjack fishing is associated with hotspots (oceanographic preference), leading to increased feeding opportunities. This study suggests that the spatial pattern of high potential fishing zones could improve fishing, management, and conservation strategies along the southern Makassar Strait.
\end{abstract}

Keywords: Empirical cumulative distribution function, generalized additive model, Katsuwonus pelamis, potential fishing zone

\section{INTRODUCTION}

Makassar Strait, as one of Indonesia's unique waters, is the primary route for the Indonesian throughflow (ITF) and passes through the South China throughflow (SCTF), which connects the Pacific and the Indian oceans. The water masses of ITF and SCTF significantly influence the oceanographic characteristics of waters (Fan et al. 2013; Li et al. 2018). The pelagic fishing productivity in these waters is very high (Nurdin et al. 2017; Putri and Zainuddin 2019). Skipjack tuna (Katsuwonus pelamis) is one of the critical economic valuable fish resources, which is the primary target of fishing (Putri and Zainuddin 2019; Putri et al. 2018a; Putri et al. 2018b). Makassar Strait is part of the Fisheries Management Area (FMA) 713 and has recorded the potential of skipjack tuna fish FMA 713 that reached 419,342 tons in 2015 (DKP 2016).

Skipjack tuna (Katsuwonus pelamis) is one of the most exploited tuna species in Indonesia (McKechnie et al. 2016). In 2014, the total of tuna caught reached 185,675 tons in Indonesia, of which almost half (around 43\%) was comprised of skipjack tuna species (Irianto et al. 2015). Skipjack tuna is the third-highest marine fish production globally, after anchovy (Engraulidae) and Alaska pollock (Gadus chalcogrammus) (FAO 2016).

Fishing operations should be carried out effectively and efficiently, which refers to exploiting the maximum amount of fish possible while remaining accountable. Potential fishing areas are places in the waters where a high abundance of fish and suitable for fishing operations. Understanding the oceanographic factors that affect fish distribution is important to find out the possible fishing grounds. This can be detected and monitored periodically through remote sensing satellite data (Nurdin et al. 2017).

Oceanographic factors become the primary factors that limit the distribution and abundance of fish (Chen et al. 2009; Mugo et al. 2010; Sartimbul et al. 2010). Warm water masses from the Pacific Ocean to the Indian Ocean and the effects of climate change such as El Nino, La Nina, and the Indian ocean dipole (IOD) will undoubtedly affect the temperature of the waters passes through the Makassar Strait. Sea surface temperature (SST) is a limiting factor for the physiology, abundance, and distribution of skipjack tuna (Mugo et al. 2010; Muhling et al. 2015; Nurdin et al. 2017; Putri et al. 2018a; Schaefer and Fuller 2019; Ashida 2020) and also indirectly encourages migration patterns (Fromentin et al. 2014). Another parameter that is no less important is the primary productivity (PP) of the oceans. PP can be used as an indicator of water fertility and refers to forming organic compounds through photosynthesis. Therefore, increased productivity will benefit species at a higher trophic level, including fish (Sigman and Hain 2012).

The distribution and migration pattern of skipjack tuna is extensive because it is a fast swimmer with long-distance highways ranging from archipelagic waters to ocean waters (Matsumoto et al. 1984; Hall and Roman 2013; Hidayat et 
al. 2019; Venegas et al. 2019). Skipjack tuna migrate in schooling because they look for waters rich in food, looking for places to spawn, and changes in several aquatic environmental factors (Mugo et al. 2010; Wang et al. 2018). Skipjack tuna is found in warmer and shallower waters than other types of tuna (Hall and Roman 2013; Grande et al. 2016; Hermida et al. 2019). Skipjack tuna fishing season in the temperate Western and Pacific Ocean (WPO) is from June to October (Ashida 2020).

Skipjack tuna lay eggs and spawn continuously throughout the year, commonly known as multiple spawners with indeterminate fecundity (Andrade and Teixeira Santos 2004; Ashida et al. 2008; Grande et al. 2012). Skipjack spawning depends on oceanographic conditions. This condition will affect reproductive characteristics such as spawning season, Batch Fecundity (BF), and Fork length at 50\% maturity (Schaefer 1987; Schaefer and Fuller 2019; Ashida 2020). In a study in the western Pacific Ocean's subtropical and temperate region, almost all female skipjack tuna that we can lay eggs appeared at SST $>24^{\circ} \mathrm{C}$. The spawning frequency of skipjack tuna in high latitudes is lower than in the tropics and subtropics due to the shorter duration of favorable sea conditions for spawning (Ashida 2020). And the upper limit for spawning is SST $30^{\circ} \mathrm{C}$ (Schaefer and Fuller 2019).

This study aimed to determine the potential fishing zones of skipjack tuna in the southern Makassar Strait.
Besides being presented spatially and temporally on the map, this study also explains how the abundance of skipjack tuna catches each concentration of SST and PP. PHI analysis was considered a valuable method in ecology by combining primary data and satellite imagery data. The PHI model was based on a suitability index that reflects habitat quality as a function of one or more environmental variables (Chen et al. 2009). The importance of determining potential skipjack tuna fishing zones formed the primary basis for this research. It is hoped that this research can be used to further research and manage skipjack fisheries in Indonesia.

\section{MATERIALS AND METHODS}

\section{Study site}

We followed the skipjack tuna purse seiner in the Makassar Strait, Indonesia to obtain fishery and oceanographic data. Makassar Strait is one of the leading fishing grounds for skipjack tuna. This area is illustrated in Figure 1. It presents a productive ecosystem; ITF carries warm water masses from the Pacific Ocean into the Indian Ocean (Iwatani et al. 2018). Some previous studies have proven that skipjack tuna habitats tend to like warm water pools (Muhling et al. 2015; Putri et al. 2018a).

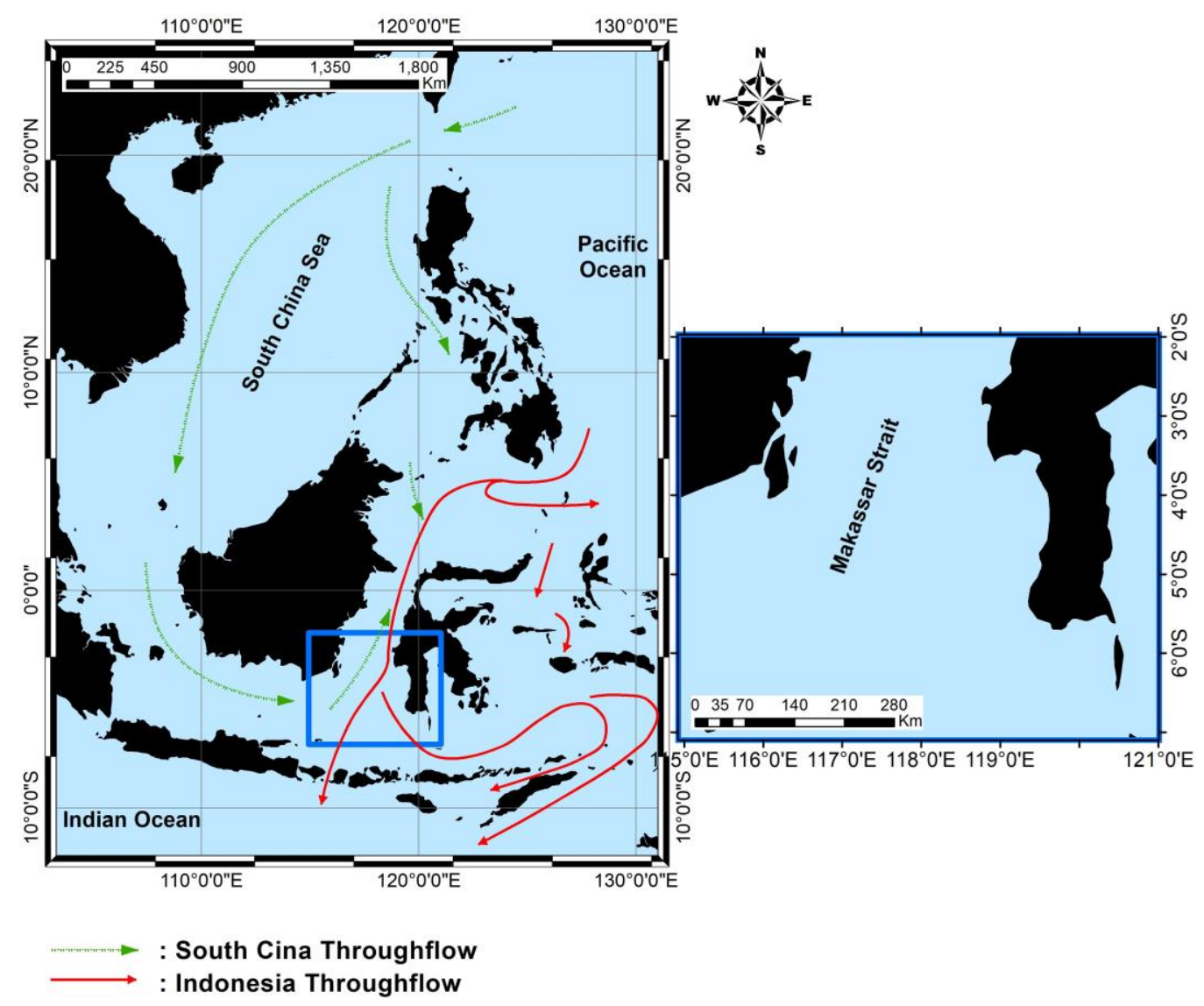

Figure 1. Study area map of Makassar Strait with the ITF and SCTF routes. The ITF and SCTF routes were obtained from (Fan et al. 2013) 


\section{Primary data}

In situ fisheries data was collected in this study. This included the daily data of catch position (latitude and longitude), the skipjack tuna catch per unit effort (CPUE), and SST data from May to December 2017 and 2018 as many as 200 fishing sets. SST data retrieval in this section only validated SST (remote sensing) data accuracy, while remote sensing data were used in the PHI model. Skipjack tuna CPUE is expressed in skipjack/setting, which indicates the number of catches (fish) per catch set. To achieve the objectives of the study, we focused our analysis on the high catch period (May to December) of skipjack tuna in Makassar Strait.

\section{Remotely sensed oceanographic data}

Remotely derived monthly oceanographic variables from May to December in 2017 and 2018 included SST and net primary production (NPP), which will be referred to as PP later in this journal. SST, moderate resolution imaging spectroradiometer (MODIS) aqua standard mapped images (SMI), with a spatial resolution of approximately 4 $\times 4 \mathrm{~km}$, were downloaded from the Ocean Color (http://oceancolor.gsfc.nasa.gov), and PP data is available at http://sites.science.oregonstate.edu/ocean.productivity/ with the same spatial resolution with SST. According to the study area, the oceanographic data was processed and cropped using the SeaWiFS Data Analysis System (SeaDAS) software version 7.5.3 (NASA, Greenbelt, MD, USA). Furthermore, the data was overlayed and analyzed in the ArcGIS 10.2 package (ESRI, Redlands, CA, USA).

\section{Generalized Additive Model (GAM)}

A GAM was used to analyze the effect of oceanographic variables on CPUE. To apply this model, we used RStudio software with the following formula (Andrade et al. 1999):

$$
\log (C P U E+1)=\propto+s(S S T)+s(P P)+\varepsilon
$$

Where: $\alpha$ is constant; $s(S S T)$ and $s(p p)$ denote the smooth spline function of SST and PP, respectively; and $\varepsilon$ represents the random error term.

\section{Empirical Cumulative Distribution Function (ECDF)}

The ECDF method was used to show the distribution of CPUE data based on oceanographic variables (SST and PP). This method is considered the best method to check the distribution of data. From the ECDF histogram, the optimum range of oceanographic variables can be seen. The ECDF formula is given below (Andrade et al. 1999; Zainuddin 2011; Sukresno et al. 2015):

$$
\begin{aligned}
& f(t)=\frac{1}{n} \sum_{i=1}^{n} l_{\left(X_{i}\right)}, \text { with the indicator function, } \\
& l_{\left(X_{i}\right)}=\left\{\begin{array}{l}
1, \text { if xi } \leq t \\
0, \text { otherwise }
\end{array}\right\} \\
& g(t)=\frac{1}{n}\left(\sum \frac{y_{i}}{\bar{y}} l_{\left(X_{i}\right)}\right) \\
& D(t)=\max |f(t)-g(t)|
\end{aligned}
$$

Where, $f(t)$ is empirical cumulative frequency distribution function; $t$ is SST or PP; $n$ is the number of the fishing ground; $l_{(x i)}$ is indication function; $g(t)$ is catchweighted cumulative distribution function; $y_{i}$ is CPUE at a catch point; $\bar{y}$ is the estimated mean value of CPUE for all fishing trips; $D(t)$ is the absolute value of the difference between the curve of $f(t)$ and $g(t)$ at any point $t$; $\max$ represents the specific value of the variables at which the difference between the two curves $(|g(t)-f(t)|)$ was maximum.

\section{Potential fishing zones}

The pelagic habitat index (PHI) method was developed to map spatially and temporally the skipjack tuna hotspots in the study area. CPUE (fish abundance index) and fishing effort frequency (fish event index) in relation to influential oceanographic variables (SST and PP) were considered. The PHI equations can be written as follows (Zainuddin et al. 2017):

$$
\begin{aligned}
& P I_{C P U E}=\frac{\sum \frac{C P U E_{i j}}{C P U E_{i} m a x}}{n} \\
& P l f=\frac{\sum \frac{F_{i j}}{F_{i} m a x}}{n} \\
& P H I=\frac{\left(P I_{C P U E}+P l f\right)}{2}
\end{aligned}
$$

Where: $P I_{C P U E}$ represents the mean probability index for skipjack tuna based on the relationship between CPUE and the two oceanographic variables (SST and PP) for each histogram graph; CPUE indicates the CPUE value of the oceanographic variable $i$ for the interval class $j$; $C P U E_{\max }$ presents the maximum CPUE value in the oceanographic variable $i ; n$ represents the total number of variables; Plf indicates the average probability index based on the relationship between the frequency of skipjack tuna catch and the oceanographic variables for the histogram graph; $F$ is the fishing frequency value of the oceanographic variable $i$ for the interval class $j ; F_{i}$ max indicates the maximum of fishing frequency value in the oceanographic variable $i$, and $P H I$ refers to the pelagic hotspot index.

This PHI analysis results use a $0-1$ weighting system (the closer the value to 1 , the higher the probability of finding skipjack tuna). A PHI value of $\geq 0.75$ indicates suitable habitat for skipjack tuna. Conversely, a lower value indicates an area with a low probability of finding skipjack tuna. The ArcGIS 10.2 Package was used to map the skipjack tuna potential fishing zones after conducting the PHI analysis.

Next, we validate the model by making scatter plots that match the PHI with skipjack tuna CPUE. This plot can prove whether this model is suitable or not.

\section{RESULTS AND DISCUSSION}

\section{Skipjack tuna in relation to oceanographic data}

The results of the GAM analysis reveal that both oceanographic variables (SST and PP) had a significant (P 
$<0.01$ ) effect on skipjack tuna catches (Table 1). The significant value of each variable was SST 0.00131 while $\mathrm{PP}$ was 0.0000000000000002. Oceanographic variables $(\mathrm{SST}+\mathrm{PP})$ explained a $41.4 \%$ deviation of the CPUE skipjack tuna. This result is in line with the results of previous studies where the SST parameter plays an essential role in the skipjack tuna catch (Mugo et al. 2010; Putri et al. 2018a; Schaefer and Fuller 2019), and PP parameters are an indicator of fertility that attract fish to come in their preferred PP concentration range (Sigman and Hain 2012).

The effect of the distribution of catches on oceanographic variables can be observed in the GAM plot (Figure 2). The dotted line shows the 95\% confidence level. The CPUE of skipjack tuna increased at SST intervals from 29 to $30{ }^{\circ} \mathrm{C}$, and $\mathrm{PP}$ concentrations ranged from $350-400 \mathrm{mg} \mathrm{C} / \mathrm{m}^{2} / \mathrm{day}$. The dotted line farther from the centerline indicates a lower confidence level, which means the unclear effect of oceanographic variables on the CPUE of skipjack tuna (Zainuddin et al. 2013).

The in-situ data histogram illustrates that skipjack tuna were caught in the SST range $28.5-31.5^{\circ} \mathrm{C}$ with the highest number of catches in the $29.5-30.0{ }^{\circ} \mathrm{C}$ range, that is, 14,714 skipjack/setting (Figure 3.A). Indeed, several studies in tropical waters have also found that skipjack tuna is caught in the same range as this study, such as a study conducted in Indonesian waters with an SST range of 29.5-31.5 ${ }^{\circ} \mathrm{C}$ (Zainuddin et al. 2017) and 30-32 ${ }^{\circ} \mathrm{C}$ (Boyce et al. 2008).

As for the water fertility parameter (PP), skipjack tuna was recorded as caught in the PP $300-750 \mathrm{mg} \mathrm{C} / \mathrm{m}^{2} /$ day and primarily caught in the range of $350-400 \mathrm{mg} \mathrm{C} / \mathrm{m}^{2} /$ day (total catch was 20,039 skipjacks/setting (Figure 3.B). Skipjack tuna tend to like ranges in the mesotrophic category (not at the highest/eutrophic water fertility level), as evidenced by skipjack tuna caught in the range 325.14$703.72 \mathrm{mg} \mathrm{C} / \mathrm{m}^{2} /$ day. These results indicate that skipjack tuna tend to be concentrated in the PP range, not too high. From Figures 3.C and 3.D, it is known that $26.90 \%$ of the catching frequency of skipjack tuna is in the SST 29.5-30 ${ }^{\circ} \mathrm{C}$ range, and $40 \%$ of the catch occurs in the PP $350-400$ $\mathrm{mg} \mathrm{C} / \mathrm{m}^{2} /$ day range. These two ranges can be used as essential references for the range of SST and PP variables favored by skipjack tuna in tropical waters.

The ECDF analysis in Figures 3.E and 3.F reinforces the results of the GAM analysis that SST and PP (independent variables) affect CPUE skipjack tuna as the dependent variable. The greater value of $D(t)$ indicated the stronger influence of each oceanographic variable (SST or PP). The results show that the strong influence of the SST variable on the CPUE skipjack tuna occurs in the range 29$30.5{ }^{\circ} \mathrm{C}$ and the PP range $350-600 \mathrm{mg} \mathrm{C} / \mathrm{m}^{2} /$ day (seen from the blue $\mathrm{D}(\mathrm{t})$ curve). The most vital relationship is shown at SST 29.5 and the PP 350 concentration. CPUE skipjack tuna tend to decline outside of this favorable range. The black graph (graph $\mathrm{f}(\mathrm{t})$ ) shows the percentage of skipjack tuna CPUE within a specific SST and PP range.

The combination of primary and secondary data has been illustrated in the map; thus, it is indicated that skipjack tuna tend to like the SST range of 29.5-30.5 ${ }^{\circ} \mathrm{C}$, and the PP concentration range is between 350 and $400 \mathrm{mg}$ $\mathrm{C} / \mathrm{m}^{2} /$ day, so this data is shown on a spatial and temporal map (Figure 4). These ranges are represented as the optimum ranges for the preferred habitat of skipjack tuna in tropical waters. Figure 4 explained that SST and CPUE data suitability is around $81.4 \%$, while PP and CPUE are about $58.1 \%$. This suitability value was calculated using the ArcGIS 10.2 Package.

Table 1. Results of the GAM model test

\begin{tabular}{|c|c|c|c|c|}
\hline Variable & Edf & Df & F value & $\operatorname{Pr}(>\mathbf{F})$ \\
\hline s(SST) & 6.810 & 7.886 & 3.356 & $0.00131^{* *}$ \\
\hline $\mathbf{s}(\mathbf{P P})$ & 5.668 & 6.820 & 10.249 & $0.0000000000000002 * * *$ \\
\hline
\end{tabular}

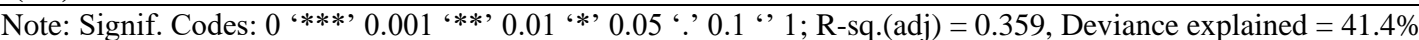

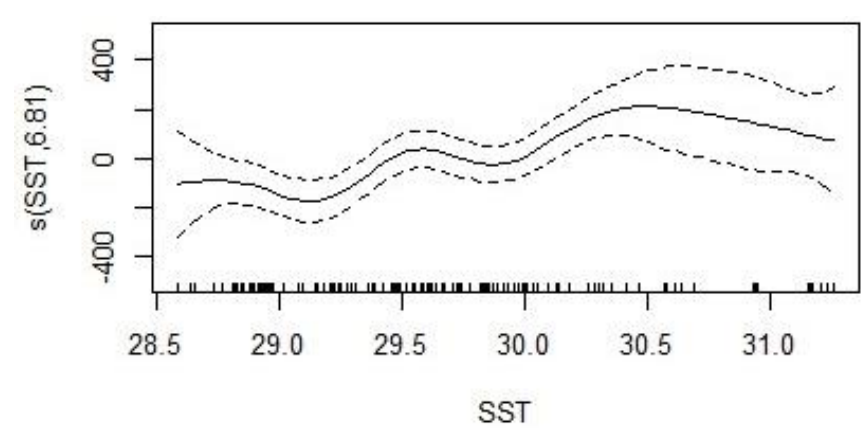

A

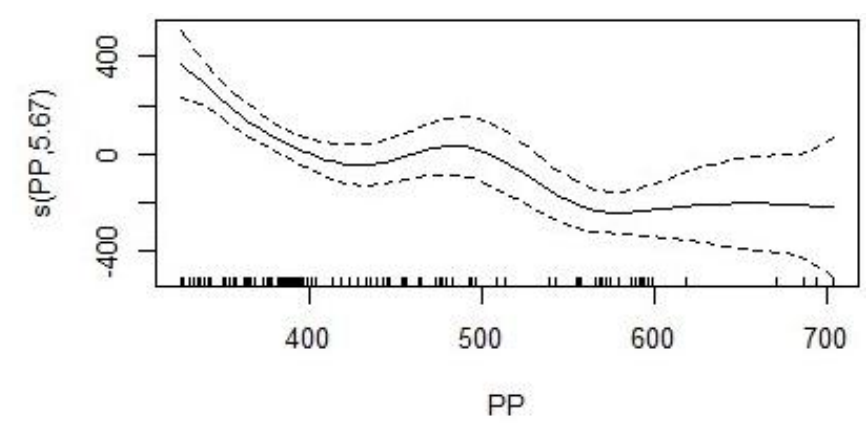

B

Figure 2. The relationship between skipjack tuna catches with SST (A) and PP (B). Black vertical stripes on the x-axis indicate the distribution of the catch 

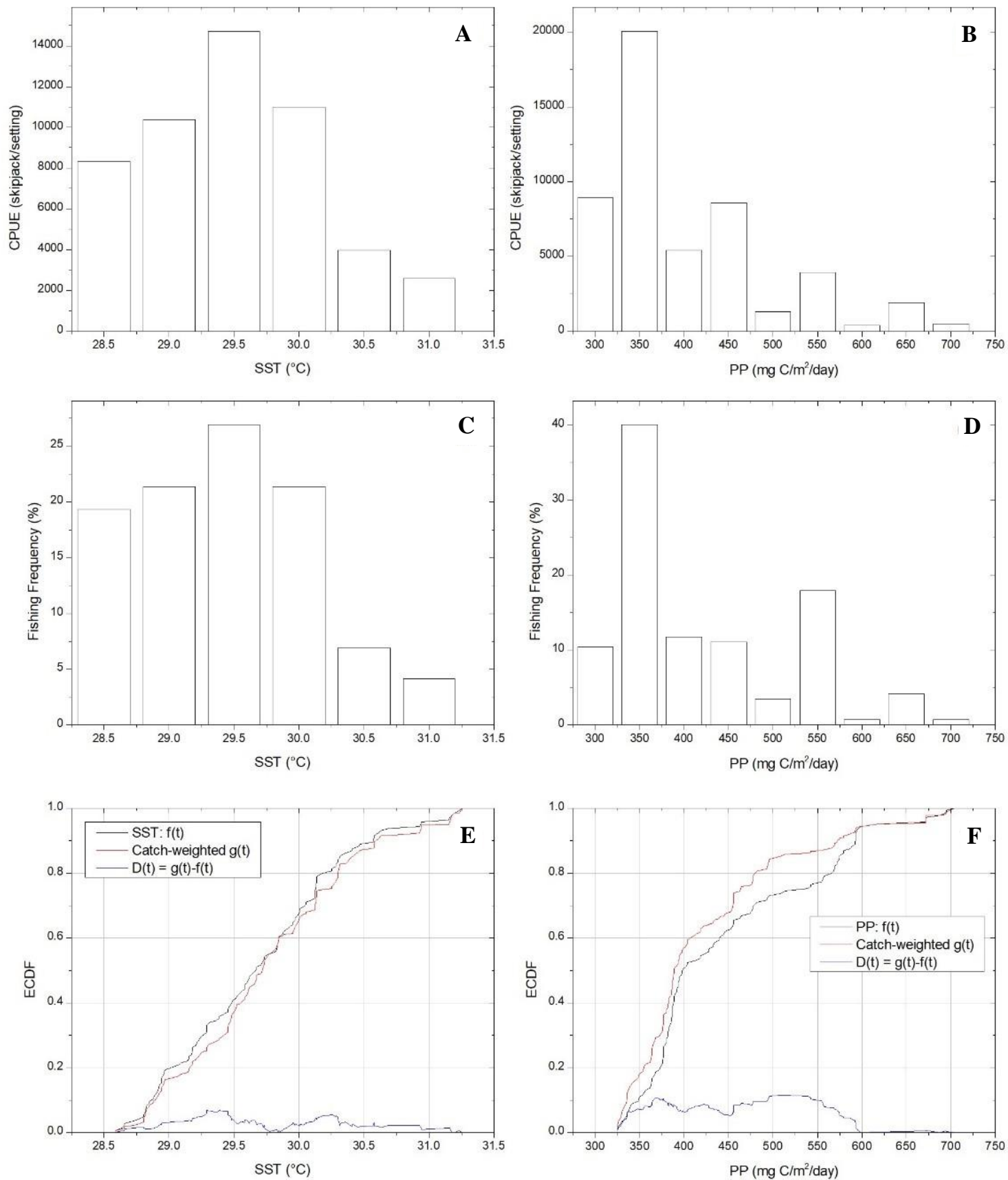

Figure 3. Total skipjack tuna CPUE in relation to (A) MODIS SST and (B) PP; fishing frequency in relation to (C) MODIS SST and (D) PP; and empirical cumulative distribution frequencies for (E) MODIS SST and (F) PP

The catch does appear to be concentrated in the optimum SST and PP ranges as obtained in the GAM and ECDF analysis, strengthening the results of the two previous analyses. The abundance of skipjack tuna is driven by optimum oceanographic conditions (SST and PP). During May-December, the central fishing of skipjack tuna in the southern Makassar Strait at the coordinate of $117^{\circ}-119^{\circ} 30 \mathrm{E}$ and $3^{\circ} 30^{\prime}-4^{\circ} 30 \mathrm{~S}$.

\section{Potential map of skipjack tuna fishing zone}

The PHI analysis model was utilized to predict the potential index of the skipjack tuna fishing zone in the southern Makassar Strait (Figure 5). Combining two oceanographic factors (SST and PP) is reasonable to predict the potential for skipjack tuna fishing grounds. In this case, a high CPUE was assumed to correspond to the oceanographic element favored by skipjack tuna (Mugo et al. 2010). The southern part of the Makassar Strait waters is a potential area for skipjack tuna fishing during the research period. The PHI value demonstrated the probability of finding skipjack tuna spatially, and the PHI value 1 indicated the likelihood of finding skipjack tuna around 100 . 


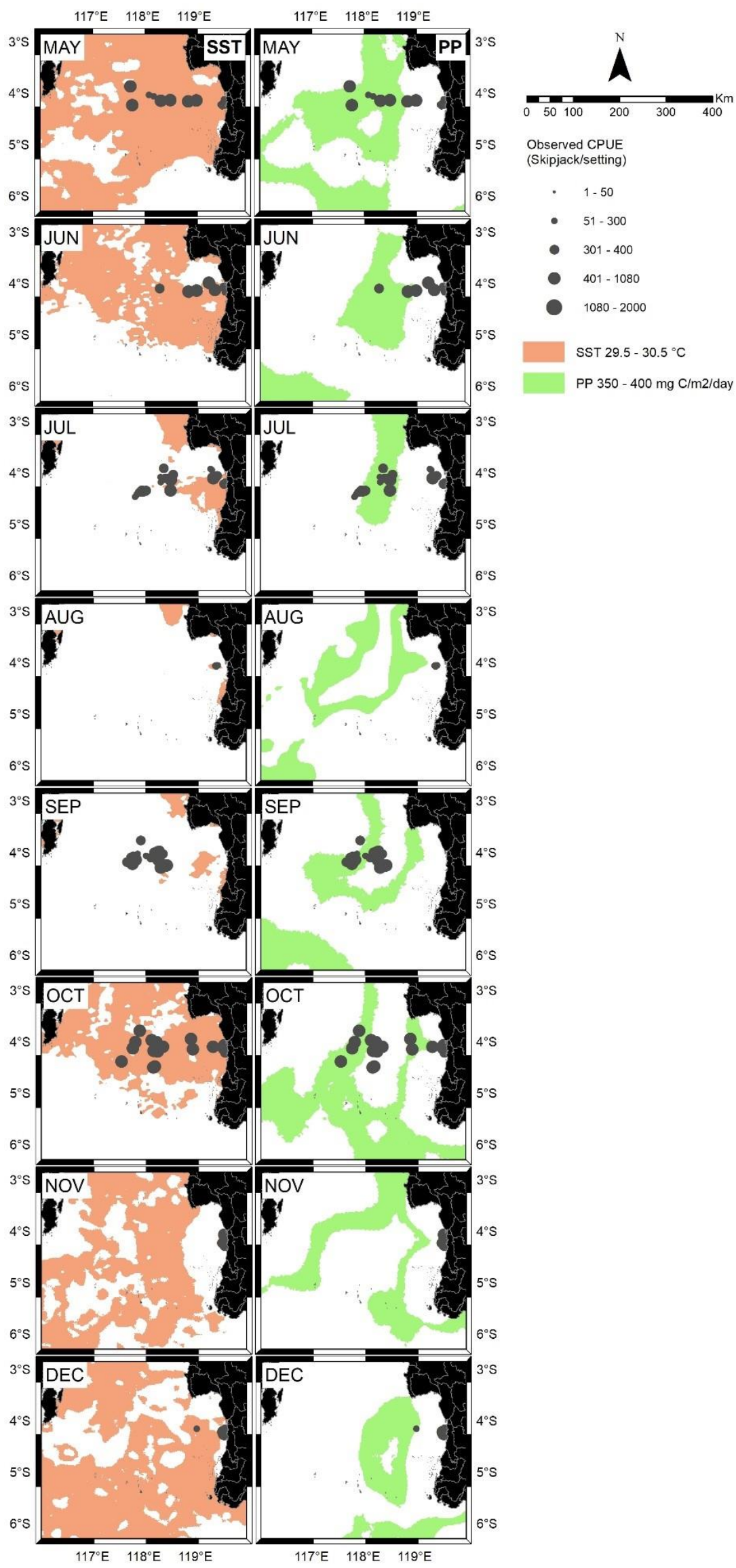

Figure 4. The spatial position of the optimum oceanographic variables (SST and PP) distribution in the southern Makassar Strait, Indonesia 

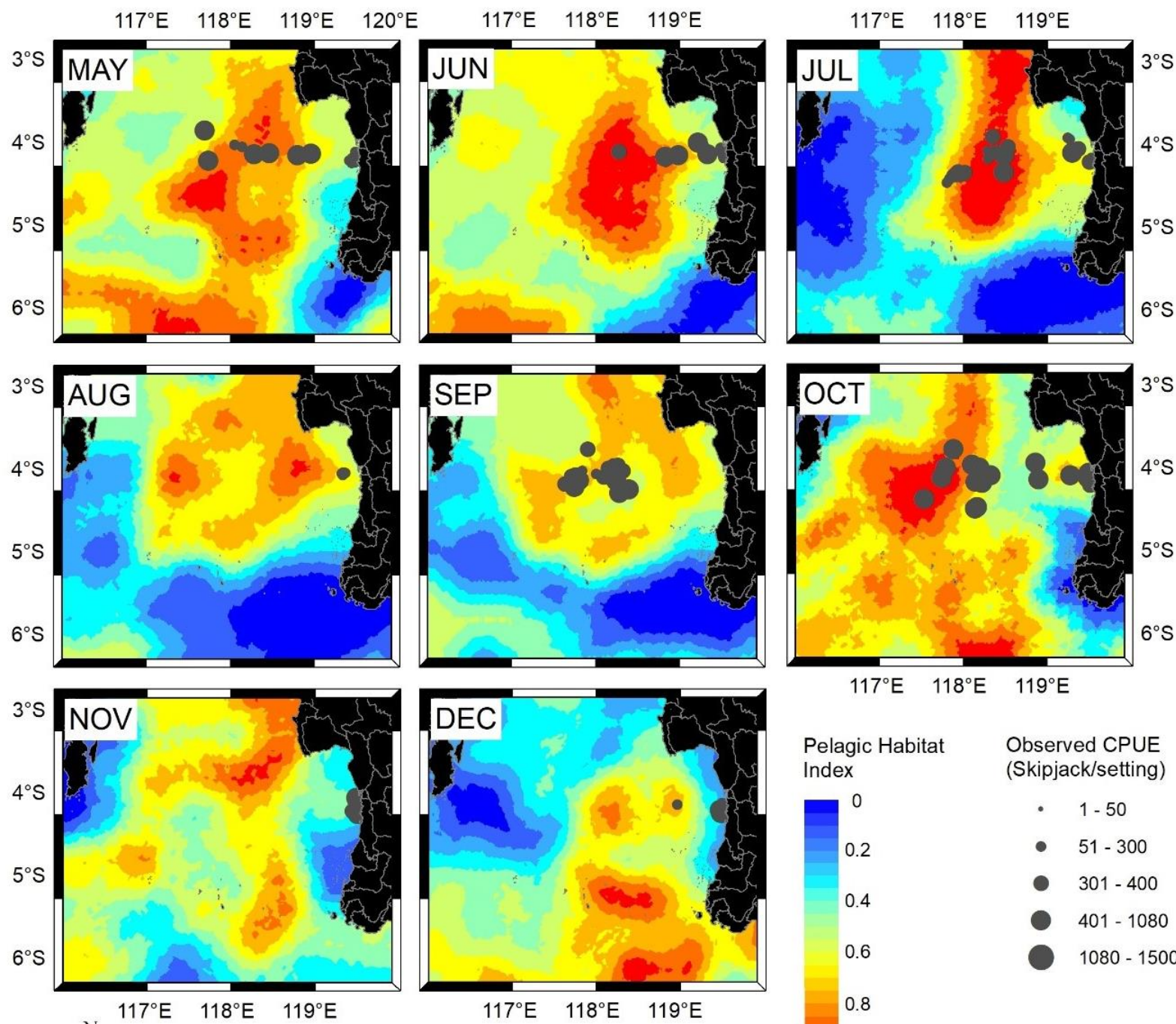

$117^{\circ} \mathrm{E} \quad 118^{\circ} \mathrm{E} \quad 119^{\circ} \mathrm{E}$
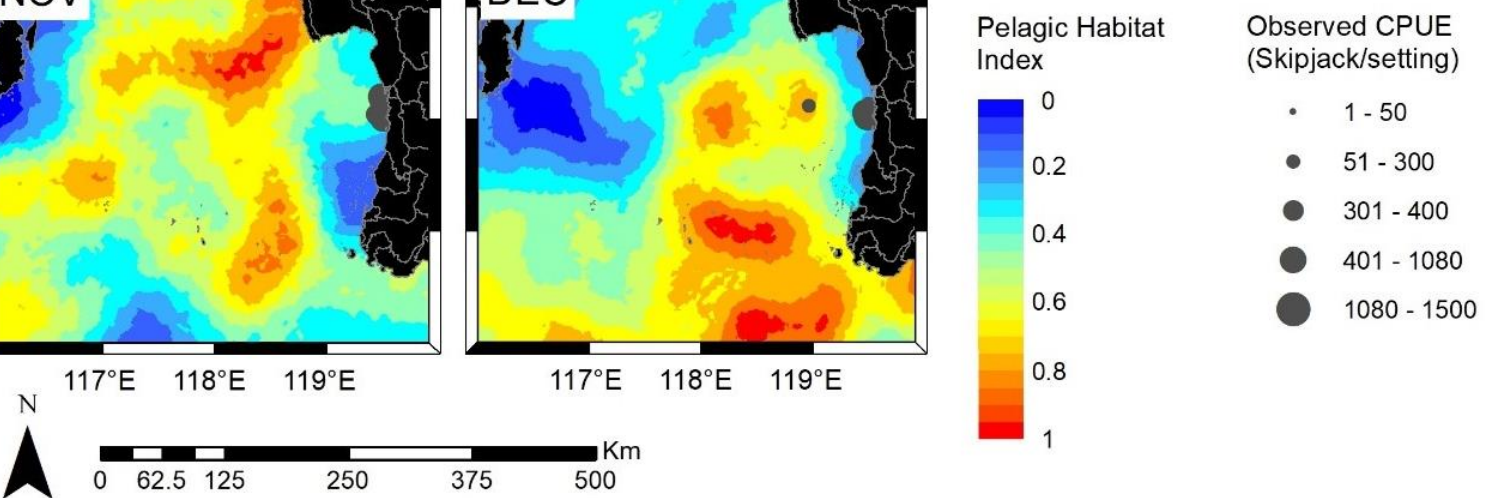

Figure 5. The potential fishing zone distribution of skipjack tuna in the southern Makassar Strait, Indonesia from May to December

The PHI analysis revealed that the potential habitat index of skipjack tuna in this region is relatively high in each research month from May to December. The most productive water areas are in the waterway with positions $3^{\circ}-6^{\circ} \mathrm{S}$ and $117^{\circ}-119^{\circ} \mathrm{E}$. The high potential area becomes sufficiently narrow only in August and September. The PHI value of 1 implies that the probability of skipjack tuna existence is $100 \%$ based on SST and PP concentration in the area. The peak season for skipjack tuna in the southern Makassar Strait occurs in May and October. Zainuddin et al. (2017) also found May as the peak season for skipjack tuna in Indonesia's waters.

\section{Discussion}

The oceanographic conditions of the preferred habitat of fish vary depending on their physiological tolerance and other limiting factors (Barkley et al. 1978; Drinkwater et al. 2010; Kiyofuji et al. 2019). Therefore, it is necessary to be aware of the oceanographic conditions that are preferred by specific fish species. Several previous studies have revealed that the optimal combination of oceanographic factors can be a way to predict fish habitat (Chen et al. 2009; Mugo et al. 2010; Yen et al. 2017; Zainuddin et al. 2017; Wang et al. 2018), although it may not be the only determining factor of skipjack tuna fishing location (Mugo et al. 2010). Therefore, in this study, we combine primary data (fishing points, number of catches, and SST) and secondary data (SST and PP satellite imagery data) and compile them in the PHI model.

SST plays a vital role in the physiological processes and distribution of fish (Muhling et al. 2015; Putri et al. 2018a; Kiyofuji et al. 2019), while the PP concentration is likely to be a pull factor for skipjack tuna to come together due to food chain events (Zainuddin et al. 2017). In addition, the water fertility factor is one of the driving factors for the existence of skipjack tuna in certain waters (Sigman and Hain 2012). The results of the GAM, ECDF, and spatial and temporal analyses both showed that the combination of 
SST and PP was highly effective in predicting skipjack tuna habitat (Figures 2, 3, and 4). Based on these results, we continue with the PHI analysis to indicate the potential fishing zone of skipjack tuna.

This study confirms previous research that skipjack tuna tend to like warm surface temperatures (Lehodey et al. 1997; Hall and Roman 2013; Grande et al. 2016; Zainuddin et al. 2017; Hermida et al. 2019). We also found that skipjack tuna habitats contained specific PP concentrations (350-400 $\mathrm{mg} \mathrm{C} / \mathrm{m}^{2} /$ day). This optimal combination of SST and PP is assumed to be strong enough to explain skipjack tuna habitat.

It is important to note that this study can be used as a new reference source for further research regarding the role of PP concentration in influencing skipjack tuna catches because there has been no previous research that specifically addresses the relationship between PP and tuna CPUE skipjack. However, even in this study, it was found that the effect of PP was stronger than SST (Table 1).

The spatial and temporal maps (Figure 5) show that the peak seasons for skipjack tuna in the southern Makassar Strait are May and October. Meanwhile, in August and September, the abundance of skipjack tuna is probably the lowest compared with other months during the study period. Two previous studies also found that May is the peak season for skipjack tuna in the Coral Triangle of Indonesia (Zainuddin et al. 2017) and the western North Pacific (Mugo et al. 2010). This reinforces the results regarding the reference for the peak season for skipjack tuna to be used to catch and manage skipjack tuna in the future.

The research period data from May to October in 2017 and 2018 showed that the total CPUE increases significantly with the increase in the PHI value $\left(\mathrm{R}^{2}=\right.$ 0.541; $\mathrm{P}<0.01$; Figure 6$)$. The PHI value has a positive correlation with the CPUE of skipjack tuna.

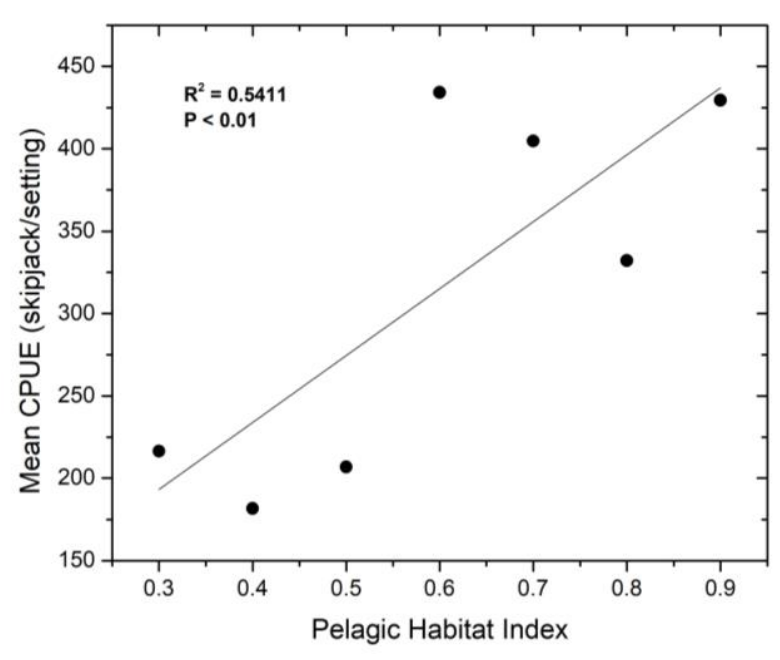

Figure 6. The relationship between mean CPUE and PHI value in the southern of Makassar Strait $\left(\mathrm{R}^{2}=0.5411, \mathrm{P}<0.01\right)$. The black dot was the mean CPUE value in each range of PHI values
The validation analysis results (Figure 6) prove that our prediction model is consistent in predicting the potential fishing zone of skipjack tuna in the southern Makassar Strait. This research can recommend that the prediction model used in this study can be used as new insights in modeling fish habitat.

In conclusion, SST and PP are essential predictors in predicting skipjack tuna habitat. This study also confirmed that the skipjack tuna fishing location was in warm waters, and the concentration of PP was specific (low). The prediction results show that the peak seasons for skipjack tuna are in May and October. These results can provide new insights for future research and management of tuna resources.

\section{ACKNOWLEDGEMENTS}

This study was financially supported by the PMDSU scholarship program of the Ministry of Research, Technology, and Higher Education of the Republic of Indonesia. We are also grateful for access to MODIS SST data sets from https://oceancolor.gsfc.nasa.gov/ and PP data from http://sites.science.oregonstate.edu/ocean.productivity/. We would like to thank four anonymous reviewers and the editor for their constructive suggestions to improve this manuscript.

\section{REFERENCES}

Andrade HA, Alberto C, Garcia E. 1999. Skipjack tuna fishery in relation to sea surface temperature off the southern Brazilian coast. Fish Oceanogr 8 (4): 245-254. DOI: 10.1046/j.1365-2419.1999.00107x.

Andrade HA, Teixeira SJA. 2004. Seasonal trends in the recruitment of skipjack tuna (Katsuwonus pelamis) to the fishing ground in the southwest Atlantic. Fish Res 66 (2-3): 185-194. DOI: 10.1016/S01657836(03)00199-1.

Ashida H, Tanabe T, Suzuki N, Fukui A, Tanaka S. 2008. Spawning frequency and batch fecundity of skipjack tuna Katsuwonus pelamis in the tropical west-central Pacific Ocean. Nippon Suisan Gakkaishi 74 (5): 802-808. DOI: DOI: 10.2331/suisan.74.802.

Ashida H. 2020. Spatial and temporal differences in the reproductive traits of skipjack tuna Katsuwonus pelamis between the subtropical and temperate western Pacific Ocean. Fish Res 221 (December 2018): 105352. DOI: 10.1016/j.fishres.2019.105352.

Barkley RA, Neill WH, Gooding RM. 1978. Skipjack tuna, Katsuwonus pelamis, habitat based on temperature and oxygen requirements. Fish Bull 76 (3): 653-662.

Boyce DG, Tittensor DP, Worm B. 2008. Effects of temperature on global patterns of tuna and billfish richness. Mar Ecol Prog Ser 355: 267276. DOI: $10.3354 /$ meps07237.

Chen X, Li G, Feng B, Tian S. 2009. Habitat suitability index of chub mackerel (Scomber iaponicus) from July to September in the East China Sea. J Oceanogr 65 (1): 93-102. DOI: 10.1007/s10872-009-0009-9.

DKP. 2016. South Sulawesi Fisheries Statistics Data. Marine and Fisheries Services, South Sulawesi, Makassar. [Indonesian]

Drinkwater KF, Beaugrand G, Kaeriyama M, Kim S, Ottersen G, Perry RI, Pörtner HO, Polovina JJ, Takasuka A. 2010. On the processes linking climate to ecosystem changes. J Mar Syst 79 (3-4): 374-388. DOI: 10.1016/j.jmarsys.2008.12.014.

Fan W, Jian Z, Bassinot F, Chu Z. 2013. Holocene centennial-scale changes of the Indonesian and South China Sea throughflows: Evidence from the Makassar Strait. Glob Planet Change 111: 111117. DOI: 10.1016/j.gloplacha.2013.08.017.

FAO. 2016. The State of World Fisheries and Aquaculture 2016 (SOFIA): Contributing to Food Security and Nutrition for All. Food and Agriculture Organization, Rome. 
Fromentin JM, Reygondeau G, Sylvain BS, Beaugrand G, Bonhommeau S, Beaugrand G. 2014. Oceanographic changes and exploitation drive the spatio-temporal dynamics of Atlantic bluefin tuna (Thunnus thynnus). Fish Oceanogr 23 (2): 147-56.

Grande M, Murua H, Zudaire I, Korta M. 2012. Oocyte development and fecundity type of the skipjack, Katsuwonus pelamis, in the Western Indian Ocean. J Sea Res 73: 117-125. DOI: 10.1016/j.seares.2012.06.008.

Grande M, Murua H, Zudaire I, Arsenault-pernet EJ, Pernet F, Bodin N. 2016. Energy allocation strategy of skipjack tuna Katsuwonus pelamis during their reproductive cycle. J Fish Biol 89 (5): 2434-2448. DOI: $10.1111 / \mathrm{jfb} .13125$

Hall M, Roman M. 2013. Bycatch and Non-tuna Catch in The Tropical Tuna Purse Seine Fisheries of The World. FAO, Rome.

Hermida M, Cavaleiro B, Gouveia L, Saraiva A. 2019. Seasonality of skipjack tuna parasites in the eastern Atlantic provides an insight into its migratory patterns. Fish Res 216 (April): 167-173. DOI: 10.1016/j.fishres.2019.04.010.

Hidayat R, Zainuddin M, Putri ARS, Safruddin. 2019. Skipjack tuna (Katsuwonus pelamis) catches in relation to chlorophyll-a front in bone gulf during the southeast monsoon. AACL Bioflux 12 (1): 209218.

Irianto HE, Wudianto W, Nugraha B, Widodo AA, Satria F, Sadiyah L. 2015. Indonesia National Report to The Scientific Committee of The Indian Ocean Tuna Commission, 2015. [Report]. Indian Ocean Tuna Commission, Seychelles.

Iwatani H, Yasuhara M, Rosenthal Y, Linsley BK. 2018. Intermediatewater dynamics and ocean ventilation effects on the Indonesian throughflow during the past 15,000 years: Ostracod Evidence. Geol 46 (6): 567-570. DOI: 10.1130/G40177.1.

Kiyofuji H, Aoki Y, Kinoshita J, Okamoto S, Masujima M, Matsumoto T, Fujioka K, Ogata R, Nakao T, Sugimoto N, Kitagawa T. 2019. Northward migration dynamics of skipjack tuna (Katsuwonus pelamis) associated with the lower thermal limit in the western Pacific Ocean. Prog Oceanogr 175: 55-67. DOI: 10.1016/j.pocean.2019.03.006.

Lehodey P, Bertignac M, Hampton J, Lewis A, Picaut J. 1997. El Nino southern oscillation and tuna in the western Pacific. Nat 389: 715718. DOI: $10.1038 / 39575$

Li M, Gordon AL, Wei J, Gruenburg LK, Jiang G. 2018. Multi-decadal time series of the Indonesian throughflow. Dyn Atmos Oceans 81: 84 95. http://dx.doi.org/10.1016/j.dynatmoce.2018.02.001.

Matsumoto W, Skillman R, Dizon A. 1984. Synopsis of biological data on skipjack tuna, Katsuwonus pelamis. In FAO Fisheries Synopsis (Issue January 1984). http://www.fao.org/docrep/017/ap940e/ap940e.pdf

McKechnie S, Hampton J, Pilling GM, Davies N. 2016. Stock Assessment of Skipjack Tuna in the Western and Central Pacific Ocean. Western and Central Pacific Fisheries Commission, Scientific Committee, Kolonia.

Mugo R, Saitoh SI, Nihira A, Kuroyama T. 2010. Habitat characteristics of skipjack tuna (Katsuwonus pelamis) in the western North Pacific: A remote sensing perspective. Fish Oceanogr 19 (5): 382-396. DOI: 10.1111/j.1365-2419.2010.00552.x.

Muhling BA, Liu Y, Lee S-K, Lamkin JT, Roffer MA, Muller-Karger F, Walter JF. 2015. Potential impact of climate change on the IntraAmericas Sea: Part 2. Implications for Atlantic bluefin tuna and skipjack tuna adult and larval habitats. J Mar Syst 148: 1-13. DOI: 10.1016/j.jmarsys.2015.01.010.

Nurdin S, Mustapha MA, Lihan T, Zainuddin M. 2017. Applicability of remote sensing oceanographic data in the detection of potential fishing grounds of Rastrelliger kanagurta in the archipelagic waters of Spermonde, Indonesia. Fish Res 196 (August 2016): 1-12. DOI: 10.1016/j.fishres.2017.07.029.

Putri ARS, Zainuddin M. 2019. Impact of climate changes on skipjack tuna (Katsuwonus pelamis) catch during May-July in the Makassar Strait. IOP Conf Ser Earth Environ Sci 253 (1): 012046. DOI: 10.1088/1755-1315/253/1/012046.

Putri ARS, Zainuddin M, Putri RS. 2018a. Effect of climate change on the distribution of skipjack tuna Katsuwonus pelamis catch in the Bone Gulf, Indonesia, during the southeast monsoon. AACL Bioflux 11 (2): 439-451.

Putri RS, Jaya I, Pujiyati S, Priatna A, Makmun A, Suman A. 2018b. Acoustic approach for estimation of skipjack (Katsuwonus pelamis) abundance in Bone Bay. IOP Conf Ser Earth Environ Sci 176 (1): 012033. DOI: 10.1088/1755-1315/176/1/012033.

Sartimbul A, Nakata H, Rohadi E, Yusuf B, Kadarisman HP. 2010 Variations in chlorophyll-a concentration and the impact on Sardinella lemuru catches in Bali Strait, Indonesia. Prog Oceanogr 87 (1-4): 168-174. DOI: 10.1016/j.pocean.2010.09.002.

Schaefer KM. 1987. Reproductive biology of black skipjack, Euthynnus lineatus, an Eastern Pacific tuna. Inter-American Trop Tuna Comm Bull 19 (2): 166-260.

Schaefer KM, Fuller DW. 2019. Spatiotemporal variability in the reproductive dynamics of skipjack tuna (Katsuwonus pelamis) in the eastern Pacific Ocean. Fish Res 209: 1-13. DOI: 10.1016/j.fishres.2018.09.002.

Sigman DM, Hain MP. 2012. The biological productivity of the ocean. Nat Educ 3 (6): 1-16.

Sukresno B, Hartoko A, Sulistyo B. 2015. Empirical cumulative distribution function (ECDF) analysis of Thunnus sp. using ARGO float sub-surface multilayer temperature data in Indian Ocean south of Java. Proc Environ Sci 23: 358-367. DOI: 10.1016/j.proenv.2015.01.052.

Venegas R, Oliver T, Brainard RE, Santos M, Geronimo R, Widlansky M. 2019. Climate-induced vulnerability of fisheries in the Coral Triangle: Skipjack Tuna thermal spawning habitats. Fish Oceanogr 28 (2): $117-$ 130. DOI: $10.1111 /$ fog. 12390 .

Wang J, Chen X, Staples KW, Chen Y. 2018. The skipjack tuna fishery in the west-central Pacific Ocean: Applying neural networks to detect habitat preferences. Fish Sci 84 (2): 309-321. DOI: 10.1007/s12562017-1161-6.

Yen K, Wang G, Lu H. 2017. Evaluating habitat suitability and relative abundance of skipjack (Katsuwonus pelamis) in the western and central Pacific during various El Niño events. Ocean Coast Manag 139: 153-160. DOI: 10.1016/j.ocecoaman.2017.02.011.

Zainuddin M. 2011. Skipjack tuna in relation to sea surface temperature and chlorophyll-a concentration of Bone Bay using remotely sensed satellite data. Jurnal Ilmu dan Teknologi Kelautan Tropis 3 (1): 82-90. DOI: 10.29244/jitkt.v3i1.7837. [Indonesian]

Zainuddin M, Nelwan A, Farhum SA, Hajar MAI, Kurnia MS. 2013. Characterizing potential fishing zone of skipjack tuna during the southeast monsoon in the Bone Bay-Flores Sea using remotely sensed oceanographic data. Intl J Geosci 4 (1): 259-266. DOI: 10.4236/ijg.2013.41a023.

Zainuddin M, Farhum A, Safruddin S, Selamat MB, Sudirman S, Nurdin N, Syamsuddin M, Ridwan M, Saitoh I. 2017. Detection of pelagic habitat hotspots for skipjack tuna in the Gulf of Bone-Flores Sea, southwestern Coral Triangle tuna, Indonesia. PLoS ONE 12 (10): e0185601. DOI: 10.1371/journal.pone.0185601. 